Giles Gasper

\title{
How to Teach the Franciscans: Robert Grosseteste and the Oxford Community of Franciscans c.1229-35
}

\begin{abstract}
Robert Grosseteste (c.1170 - 1253), polymath and sometime bishop of Lincoln, was between about 1229 and 1235 the first lector to the newly established Franciscan community at Oxford. This paper will explore what Grosseteste may have taught the Franciscans, based on 1. the results of large-scale interdisciplinary project on Grosseteste's scientific works, 2. Grosseteste's correspondence, pastoral care treatises, theological works, Dicta, and his Anglo-Norman poem Le Chateau d'amour, and 3. the Franciscan core of the Lanercost Chronicle and Thomas of Eccleston's De adventu (on the arrival of the Franciscan's in England). The chapter re-considers the effect of Grosseteste's lectorship and what it is possible to know about its details. ${ }^{1}$
\end{abstract}

Robert Grosseteste is well-known for his support for the Franciscan Order, and his warm relations with many brothers of the English province. The Dominican Nicholas Trevet (c.1257x65 - in or after 1334), writing between 1314 and 1320, summarized this relationship in the following way:

He embraced the brothers of the [mendicant] orders, both the Preachers [Dominicans] and Minors [Franciscans], with sincere affection, and had them continuously in his household, counting it a delight to confer with them on Scripture. Above all others he had as his close friend Brother Adam of Marsh, from the diocese of Bath, of the Franciscan order, a celebrated and famous teacher in sacred theology/learning; on account of whose affection he left all his books as a legacy to the Franciscan community of Oxford. ${ }^{2}$

1 A significant debt of thanks goes to Dr Sigbjørn Sønnesyn for his advice and help with this paper,
and to the Centre for Catholic Studies, Durham University for the opportunity to seek feedback on an
earlier version of this paper at a conference to mark the meeting of Saint Francis and Sultan Malek Al-
Kami, The Franciscan Legacy from the 13th Century to the $21^{\text {st }}$ Assessing the Continuing Significance of
St Francis and Franciscan Traditions of Theology, Spirituality, and Action, November 5-7, 2019. My
thanks too to all of the participants in the e-conferences on 'Thirteenth-Century English Franciscan
Thought' organized over the summer in 2020.
2 Nicholas Trevet, Annales ex regum Angliae, $1135-1307$, ed. Thomas Hog (London: English Historical
Society, 1845) p. 243: 'Hic fratres ordinis, tam Praedicatorum quam Minorum, sincera caritate am-
plectens, eos habuit continue in comitiva sua, delicias computans cum eis de Scripturis conferre.
Prae ceteris etiam familiarem habuit fratrem Adam de Marisco Bathoniensis diocesis, ordinis Minor-
um, in sacra theologia doctorem eximium et famosusm; ob cuius affectionem libros suos omnes con-
ventui fratrum Minoroum Oxoniae in testament legavit.' On the inadequacies of Hog's edition, see
Frank A. C. Mantello, 'The Editions of Nicholas Trevet's Annales sex regum Angliae,' Revue d'histoire
des textes 10 (1982 for 1980), pp. 257-75; on Trevet see James G. Clark, 'Trevet, Nicholas (b. 1257x65, $d$. 
The continuing relation with Greyfriars, Oxford, and the emphasis on scripture first, are worth noting here. The Lanercost Chronicle, a Franciscan chronicle adapted at the Augustinian Priory of Lanercost, composed in two parts (1201-97 and 1298-1346), speaks to Grosseteste's use of the Franciscans within the diocese of Lincoln.

He kept such a jealous watch over the cure of souls, moreover, that, excepting long prayer vigils with which he reconciled God and sinners, he did not cease from going around visiting, and preaching to the common people, or, when he was not free to do so, he deputed the Franciscans, whom he kept continuously with him for the salvation of souls. ${ }^{3}$

Lincoln was a large territory to cover in the period: all of Lincoln, Huntingdon, Northampton, Leicester, Oxford, Buckingham, Bedford, Rutland, and most of Hertford, in eight archdeaconries, 77 deaneries, and c.1600 parishes. ${ }^{4}$ The purposeful and positive role Grosseteste saw for mendicant learning and pastoral care, and their recognition of his support is corroborated by the Dominican Father Hubert's verse Life of Grosseteste completed soon after the latter's death in 1253.

They who deliver the word of God [Dominicans], and the Friars Minor [Franciscans], Mourn the death of their Father.

He was the father and guardian for both orders.

Each order was always admirable to him.

The presence of the brothers pleased him, as did their

Arrival, their multitude, and frequent conversation.

He decreed that the brothers should have partners to share

the burden, so that they might more easily endure the burden of their labour.

As a mother to her new-born, he fostered, loved,

Protected, fed, and valued them.

Whether in private or in public, he did not know how to live without the brothers,

They were also to hand, and he always stayed by them.

Who will now be the guardian of the orphan brothers, to whom

They may flee, and from whom they may receive help?

in or after 1334),' Oxford Dictionary of National Biography (Oxford: Oxford University Press, 2004) [http://www.oxforddnb.com/view/article/27744, accessed 22 March 2017].

3 Joseph Stevenson, Chronicon de Lanercost, 1201-1346 [Lanercost Chronicle] (Edinburgh: The Bannatyne Club, 1839), s.a.1235, p. 43: 'Animarum vero curae tantum incubuit, quod, exceptis longis orationum vigiliis quibus reconciliabat Dominum peccantibus, non ceslabat circuire visitando, et in vulgari populo praedicando, vel quando fibi non vacabat fratres Minores subrogando, quos quasi continue fecum propter animarum salutem detinebat.' The original was known in the 16th century as the chronicle of Friar Richard of Durham, although it was the work of two separate Franciscans; see A. G. Little, 'The Authorship of the Lanercost Chronicle,' The English Historical Review 31 (1916), pp. 269-79 [https://doi.org/10.1093/ehr/XXXI.CXXII.269].

4 Richard W. Southern, Robert Grosseteste: The Growth of an English Mind in Medieval Europe, 2nd ed. (Oxford: Oxford University Press, 1992), p. 235. 
Behold as Robert is laid low so is the defence of the brothers,

Aid languishes, and eloquence is silent. ${ }^{5}$

Grosseteste's letter collection includes exchanges extolling the virtues of Franciscans as an order and as individuals. ${ }^{6}$ In a sermon for Advent, on the apocalyptic imagery of Luke 21:25 ("And there shall be signs in the sun, and in the moon, and in the stars'), Grosseteste compares traditional and mendicant forms of regular life, using the analogy of the luminaries: 'But recently the dark cloud of poverty has burst forth in such an effulgence of heavenly living among the Friars Preachers and among the Friars Minor who profess the Rule of the blessed Francis that the very sun of the earlier order [Benedictines] seems in comparison with the later one much dimmed. ${ }^{77}$ Light was an essential a part of Grosseteste's scientific and theological vision, and, as the lucent vocabulary applied to the mendicants indicates, for pastoral care as well.

\section{Oxford}

It is the Oxford Franciscan community with whom Grosseteste had the closest relations, and who would themselves take an active part in the preservation of his memory, and the promotion of his work. Thomas of Eccleston, the chronicler of the arrival and establishment of the Friars Minor in England, marks the foundation of the first Oxford house in 1224 and some of the early members of the community. ${ }^{8}$ Such mat-

5 Father Hubert, De Vita Beati Roberti Quondam Lincolniensis Episcopi, in Richard W. Hunt, 'Verses on the Life of Robert Grosseteste,' Mediaevalia et Humanistica 1 (1970), pp. 246-51 in pp. 241-51: 'Verbum qui domini dispensant atque Minores / Patrem deplangunt occubuisse suum. / Hic pater et tutor fuit ordinis huius et huius / Ordo gratus ei semper uterque fuit. / Illi complacuit fratrum presencia, fratrum / Adventus, fratrum copia, sermo frequens. / Consortes oneris fratres, decrevit habendos, / Ut levius posset ferre laboris onus. / Ut fetus teneros mater, sic fovit, amavit, / Protexit, pavit, appreciavit eos. / Vivere nescivit sine fratribus intus et extra, / Semper habebat eos, semper adhesit eis. / Quis modo tutor erit pupillis fratribus, ad quem / Confugient, a quo subvenietur eis? / Presidium fratrum iacet ecce iacente Roberto, / Auxilium languet eloquiumque tacet.'

6 For example, Robert Grosseteste, Epistolae, ed. Henry Richards Luard (London: Longman, Green, Longman and Roberts, 1861), Letter 41, pp. 133-34. English translation: The Letters of Robert Grosseteste, Bishop of Lincoln, trans. F. A. C. Mantello and Joseph W. Goering (Toronto: University of Toronto Press, 2010), pp. $160-62$.

7 Michael Robson, 'Robert Grosseteste's Two Sermons to the Friars Minor in Commendation of Evangelical Poverty,' in Robert Grosseteste and His Intellectual Milieu, ed. John Flood, James R. Ginther and Joseph W. Goering (Toronto: Pontifical Institute of Mediaeval Studies, 2013), p. 107 and n. 20 in pp. 102-27: 'Sed nuper nubes obscura pauperitas in tantam erupit lucem celestis conversacionis in fratribus predicatoribus et in fratribus minoribus, qui profitentur regulam beati Francisci quod ipse sol prioris religionis in comparcione subsequentis multum videtur obscurari (...).'

8 Thomas of Eccleston, Tractatus De Adventu Fratrum Minorum in Angliam, ed. A. G. Little (Manchester: Manchester University Press, 1951), p. 22. 
ters were not accorded any great attention by non-Franciscan authors, for example, Matthew Paris. Grosseteste is an important presence in Eccleston's work, as the first lector to the Oxford community from $c .1229 / 30$ (the exact date is impossible to identify) until his election as Bishop of Lincoln in $1235 .{ }^{9}$ Of his appointment as lector Eccleston remarks:

In that celebrated place, where the first learning flourished in England, and where the community of scholars was used to meeting, Brother Agnellus established a sufficiently worthy school at the brothers' location [Greyfriars], and requested and secured agreement from Robert Grosseteste of sacred memory that he would lecture there for the brothers. Under him they made inestimable progress within a short period of time, both in questions and in subtle morality suitable for preaching. When he therefore was translated by divine providence from the magisterial [office] to an episcopal seat, Master Peter, who was later appointed as bishop in Scotland, lectured to the brothers at the same place. ${ }^{10}$

This passage presents a number of issues for note: the importance to this community of scholastic learning, the 'questions', and preaching and its individual formation. Further questions might also be raised as to the nature of the community, the significance of Grosseteste's appointment and his reputation in 1229/30. Some context is needed and the implications of the various items of evidence are not entirely straightforward.

There are few details for Grosseteste's early life. ${ }^{11}$ An early attestation as Master in a charter of Hugh, Bishop of Lincoln, and a position 1195-98 in the household of William de Vere, Bishop of Hereford, indicate a date of birth in around 1170. It is impossible to be certain where Grosseteste undertook higher learning, though it was possibly in the Cathedral school at Lincoln. He seems to have been in France in 1209-14 during the interdict on England and probably retained connections with leading figures in the Diocese of Hereford, notably Hugh Foliot, Archdeacon of Shropshire and later Bishop of Hereford (1219-34). Visits to Paris between 1215 and 1225 or so seem probable given his later friendships, including William of $\mathrm{Au}$ vergne, and the range of philosophical and theological interests, including light,

9 A. G. Little, The Grey Friars in Oxford (Oxford: Oxford University Press, 1892), p. 30.

10 Eccleston, Tractatus De Adventu, Collatio XI, 'De promotione lectorum', p. 48: 'Ampliato loco, ubi principale studium florebat in Anglia, et ubi universitas scholarium convernire consuevit, fecit frater Agnellus scholam satis honestam aedificari in loco fratrum, et impetravit a sanctae memoriae magistro Roberto Grosseteste, ut legeret ibi fratribus. Sub quo inaestimabiliter infra breve tempus tam in quaestionibus quam praedicationi congruis subtilibus moralitatibus profecerunt. Ipso igitur ab cathedra magistrali in cathedram pontificalem providentia divina translato, legit fratribus ibidem magister Petrus qui postmodum in episcopum in Scotia promotus est.'

11 For a summary Giles E. M. Gasper, Cecilia Panti, Hannah E. Smithson, Tom McLeish, Sigbjørn Sønnesyn, David Thomson, et al, Knowing and Speaking: Robert Grosseteste's De artibus liberalibus 'On the Liberal Arts' and De generatione sonorum 'On the Generation of Sounds', esp. Chap. 1, pp. 15-21 and Chap.9, pp.203-14. 
which he shared with contemporary Parisian theology. ${ }^{12}$ Although plausible, a connection with Oxford before Grosseteste's appointment as lector to the Franciscans is difficult to demonstrate despite the long-standing (and faulty) tradition which made him the first chancellor in 1215 and suggestions that he was already lecturing in the schools from about $1225 .{ }^{13}$

Whatever suggestions are made, the first evidence for Grosseteste's formal involvement at Oxford post-dates 1229, the year in which he recalled having heard Agnellus of Pisa, provincial ministers of the Franciscans in England, preach in the city. ${ }^{14}$ In 1231 Grosseteste, still archdeacon of Leicester, was named as part of a delegation to seek the freedom of several students who had been caught hunting, and in 1234, no longer archdeacon, he was part of a commission together with the Dominican Robert Bacon and the chancellor of the university to remove prostitutes from the city. ${ }^{15}$ On a similar theme of moral reform is another early letter from Grosseteste to a master in theology admonishing him to control his carnal appetites. ${ }^{16} \mathrm{~A}$ date of 1232-34 can be suggested for the letter since Grosseteste is not archdeacon nor yet bishop, though clearly operating in a scholarly milieu. A reference to the unnamed master as a preacher of the cross might be connected to the preaching of crusade ordered by Pope Gregory IX in 1234. Interestingly too Grosseteste describes himself at the end of the letter as inferior to, and less experienced than, his addressee. This would fit with the suggestion made particularly by Goering that Grosseteste took up formal theological studies late in life and perhaps co-terminously with his engagement to the Franciscans. ${ }^{17}$ That would make Grosseteste as Master of Arts inferior to the lustful Master of Theology, and less experienced.

When Grosseteste took up his role with the Franciscans he was probably sixty and had been promoted rapidly since receiving what appears to have been his first benefice, the rectory of Abbotsley in Lincoln diocese only in $1225 .{ }^{18}$ He was appointed

12 Joseph W. Goering, 'When and Where did Grosseteste Study Theology?' in Robert Grosseteste: New Perspectives on His Thought and Scholarship, ed. James McEvoy (Turnhout: Brepols, 1995), pp. 39-43 in pp. 17-51.

13 See Daniel A. Callus, 'Robert Grosseteste as Scholar,' in Robert Grosseteste, Scholar and Bishop, ed. Daniel A. Callus (Oxford: Oxford University Press, 1955), pp. 7-10 in pp.1-69, esp. p. 9; G. Pollard, 'The Legatine Award to Oxford in 1214 and Robert Grosteste,' Oxoniensia 39 (1974), pp. 62-72. Robert Grosseteste, ed. James McEvoy (Oxford: Oxford University Press, 2000), pp. 22-29, follows this position. The question will be revisited in Giles E. M. Gasper, Tom McLeish, Hannah Smithson, Sigbjørn Sønnesyn et al., Mapping the Heavens: Robert Grosseteste’s De sphera 'On the Sphere' (Oxford: Oxford University Press, 2021), Chapter 1 (Giles E. M. Gasper). On Grosseteste and the Oxford schools see Southern, Robert Grosseteste, pp. 70-75.

14 Grosseteste, Epistolae, ed. Richards Luard, Letter 2, pp. 17-21.

15 Close Rolls of the Reign of Henry III, 1227-1231 (London: HMSO, 1902), p. 520; Close Rolls of the Reign of Henry III, 1231-1234 (London: HMSO, 1905), p. 568.

16 Grosseteste, Epistolae, ed. Richards Luard, Letter 10, pp. 48-50. For dating notes see Mantello and Goering, The Letters of Robert Grosseteste, pp. 80-82, nn. 1-3.

17 Goering, 'When and Where did Grosseteste Study Theology?', pp. 43-46.

18 Rotuli Hugonis de Welles, ed. F. N. Davis, vol. III (London, Canterbury \& York Society, 1908), p. 48. 
archdeacon of Leicester in 1229, and bishop of the diocese six years later. It is at the point of his promotion to archdeacon that he seems to have encountered mendicant evangelism in a powerful way. In the same year Grosseteste, as noted above, heard Jordan of Saxony, the Master-General of the Dominicans, preach in Oxford, on the sin of pride and academic achievement; later, when bishop, Grosseteste corresponded with Jordan recalling their conversations during this visit. ${ }^{19}$ This encounter was, presumably, an important part of the process by which Agnellus came to appoint Grosseteste as lector. ${ }^{20}$

Grosseteste remained as archdeacon until 1232 when he resigned from this and all other positions, keeping only the income from St Margaret's Leicester, his prebend at Lincoln Cathedral. ${ }^{21}$ This rather dramatic rejection of everything but a single benefice he reported in letters to his sister and to his friend, and soon-to-be Franciscan friar, Adam Marsh. ${ }^{22}$ The extent to which this was in response to the mendicant life and ideals to which he had been exposed might be pondered.

There are other sources of connection between Grosseteste and the friars which relate to his Hereford connections. Grosseteste's probable sponsor and supporter Hugh Foliot who, as bishop of Hereford, may well have encountered the first Dominicans to enter England, when returning from pilgrimage to Santiago da Compostela at Easter 1221 in company with Peter des Roches. ${ }^{23}$ Peter was Bishop of Winchester, tutor and guardian to the king, and one of the triumvirate ruling England from 1219 during Henry III's minority, but lost power and influence as the king's majority drew closer, and the pilgrimage almost certainly had a political aspect. ${ }^{24}$ The Franciscans arrived in England in 1224, and were established at Canterbury, Oxford, and also Hereford before 1228; in the case of the latter supported by bishop Hugh. Whether the establishment of the order at Hereford had any further significance for Grosseteste's appointment at Oxford is impossible to say, but a broader range of possibilities should be borne in mind.

19 Grosseteste, Epistolae, ed. Richards Luard, Letter 40, pp. 131-33.

20 See Eccleston, Tractatus De Adventu, p. 48.

21 Southern, Robert Grosseteste, pp. 74-75.

22 Grosseteste, Epistolae, ed. Richards Luard, Letters 8-9, pp. 43-47.

23 Nicholas Trevet, Annales, ed. Hog, p. 209; on the pilgrimage itself Annales de Dunstaplia, in Annales monastici, ed. Henry Richards Luard, vol. iii (London: Longman, Green, Longman, Roberts, and Green, 1864), p. 68

24 D. A. Carpenter, The Minority of Henry III (London: Methuen, 1990), pp. 239-43; Nicholas Vincent, Peter des Roches: An Alien in English Politics, 1205-1238 (Cambridge: Cambridge University Press, 1996), pp. $199-204$. 


\section{What was Grosseteste's Academic Work when Lector?}

The current consensus of the chronology of Grosseteste's works places the beginning of his lectorship at an intriguing juncture. It is probable that his final treatise on natural phenomena, On the Rainbow, was completed in the year or two around 1230s. ${ }^{25}$ This treatise brings to a close a long period of reflection on natural philosophy, commencing at the end of the 12th century, working through a significant body of Latin translation of Aristotle, Ptolemy, and Islamicate authors such as Abu Ma'shar, Ibn Sina, Ibn Rushd, Thābit, and al-Bitrūjī. Twelve shorter treatises are accompanied by a full commentary on Aristotle's Posterior Analytics, a partial commentary on his Physics and textbooks On the Sphere and the Compotus/On Time Reckoning. ${ }^{26}$ The fruits of this labour are to be seen in Grosseteste's later biblical exegesis, pastoral care literature, translations from Greek authors (including Aristotle), and speculative theology. How natural philosophy is put to the service of theology is a key element in Grosseteste's theological enterprise.

This enterprise coincides most clearly with Grosseteste's period as lector, although this also involves the complex, and probably unfeasible task, of identifying when his regent mastership in theology began. ${ }^{27}$ It concluded at the same time as his office with the Franciscans in 1235 and his election to Lincoln. Various dates for its

25 For the current consensus on the chronology of these writings see Cecilia Panti, 'Robert Grosseteste and Adam of Exeter's Physics of Light, Remarks on the Transmission, Authenticity, and Chronology of Grosseteste's Scientific Opuscula,' in Robert Grosseteste and His Intellectual Milieu, ed. Flood, Ginther, and Goering, pp. 165-190, summarised at p. 185.

26 The current critical editions for these texts are: Robert Grosseteste, Commentarius in VIII Libros Physicorum Aristotelis, ed. R. C. Dales (Colorado: University of Colorado Press, 1963); Robert Grosseteste, Commentarius in Posteriorum Analyticorum libros, ed. Piero Rossi (Florence: Olschki, 1981); Robert Grossseteste, Compotus, ed. and trans. Alfred Lohr and C. Philipp E. Nothaft (Oxford: Oxford University Press, 2019). The scientific opuscula were first edited by Ludwig Baur, Die philosophischen Werke des Robert Grosseteste, Bishofs von Lincoln (Aschendorff: Münster i.W., 1912). A number have been re-edited: Cecilia Panti, Moti, virtù e motori celesti nella cosmologia di Roberto Grossatesta: Studio ed edizione dei trattati 'De sphera', 'De cometis', 'De motu supercelestium' (Florence: Sismel-Edizioni del Galluzzo, 2001). For the other scientific opuscula see Cecilia Panti, 'Robert Grosseteste's De luce: A Critical Edition,' in Robert Grosseteste and His Intellectual Milieu, ed. John Flood, James R. Ginther, and Joseph W. Goering (Toronto: Pontifical Institute of Mediaeval Studies, 2013), pp. 193238 and translated by Neil Lewis in the same volume, pp. 239-47. The text of the critical edition of the De luce, without critical apparatus is printed in Cecilia Panti, Roberto Grossatesta, La Luce (Pisa: Edizioni Plus-Pisa University Press, 2011); G. Dinkova-Bruun, et al., The Dimensions of Colour, Robert Grosseteste's De colore (Toronto: Pontifical Institute of Mediaeval Studies, 2013); the remaining opuscula will be published from the Ordered Universe project in six volumes, the first of which is in print: Gasper, Panti, Smithson, McLeish, Sønnesyn, and Thomson, etal, Knowing and Speaking. 27 James Ginther, Master of the Sacred Page: A Study of the Theology of Robert Grosseteste, ca. 1229/ 30-1235 (Aldershot: Ashgate, 2004), p. 5. 
inception have been proposed from 1214 to 1225, all with their flaws, with issues relating to: the necessity or not of priesting, and when that took place; different models and assumptions for Grosseteste's career, and whether he undertook theological training in Paris in the first decade of the 13th century; and his putative role as Magister scholarum. The Franciscan lectorship itself forms a significant element in the evidence, suggesting a regency from about 1229 to 1235, and while an earlier date should not be ruled out entirely it is difficult to establish with any certainty. ${ }^{28}$

Whatever the case, the bulk of Grosseteste's theological writings, the relative dating of which is as complex as the case for the scientific works, seem to have been composed during his time with the Franciscans. The corpus of work comprises the Commentary on Psalms, the extracts of glosses on the Pauline Epistles and comments on Galatians, the Hexaemeron and the De cessatione legalium (preserving the lectures on Genesis, Daniel and Isaiah), the records of disputation, De dotibus, De veritate, De ordine, and De libero arbitrio, the Dicta, a number of sermons including three to the Franciscan community, the pastoral works De decem mandatis and the Notus in Iudea Deus, the twin treatises on angels and form which also circulate as Letter 1, and the next nine or so letters of his collection (most of which relate to other business than teaching, including legal cases and the resignation of his archdeaconry), and the Anglo-Norman verse treatise the Chateau d'Amour. ${ }^{29}$

The implications of this exegetical, theological, and pastoral output are important for Grosseteste's education of the Franciscans. A strong emphasis on the doctrine of creation ex nihilo as cardinal, the fall of humanity and its consequences, and the restorative and redeeming work of Christ (including a role for the devil) form the core concerns. Differing levels of expertise are catered for across the range of Grosseteste's writing, which may reflect different audiences as well as different authorial intentions. It is possible that Grosseteste taught other students than only the Franciscans at Oxford. The importance of pastoralia, the literature of pastoral care should not be underestimated either. ${ }^{30}$ Interest in pastoralia required theolog-

28 Callus, 'Robert Grosseteste as Scholar,' pp. 6-11; McEvoy, Robert Grosseteste, p. 25; Southern, Robert Grosseteste, pp. 69-71; Ginther, Master of the Sacred Page, p. 20. See also Goering 'When and Where did Grosseteste Study Theology?' The issues turn on, first, the question of whether Grosseteste could have learnt and taught theology as a deacon rather than as a priest: Southern insists on the priesthood, and a later date (1225) (Southern, Robert Grosseteste, p. 70); McEvoy disputed whether this was necessary (McEvoy, Robert Grosseteste, pp. 22-26). Goering in his summary, 'When and Where did Grosseteste Study Theology?' supports Southern on the later date. The second question concerns the chancellorship of the University at Oxford and its relationship to a regent mastership in theology (see above, n. 12).

29 Ginther, Master of the Sacred Page, pp. 13-24; Michael Robson, 'Robert Grosseteste and the Franciscan School at Oxford (c. 1229-1235),' Antonianum 95 (2020), p. 355 in pp. 345-82.

30 Joseph W. Goering and F.A.C. Mantello, 'The Meditaciones of Robert Grosseteste,' Journal of Theological Studies 36 (1985), pp. 118-28; Joseph W. Goering and F.A.C. Mantello, 'The Perambulauit Iudas... (Speculum confessionis) Attributed to Robert Grosseteste,' Revue Bénédictine 96 (1986), pp. 125-68; see also Leonard Boyle, 'Robert Grosseteste and the Pastoral Care,' Medieval and Renais- 
ical literacy but not theological training of the sort demanded in the magistracy. In terms of sermons this underpins the crucial movement from classroom to preaching, part of the life of the university, and essential for the evangelical mission to the wider Christian community. By the time of his appointment to the Franciscans Grosseteste was also a master of the field of confessional and penitential literature, an interest which began perhaps as early as 1200 with the De modo confitendi, with other texts produced at regular intervals. ${ }^{31}$ The Meditations seem to date to about 1215 or so, the Templum Dei from c.1219 onwards, with the Speculum ecclesiae following in the mid-1220s. ${ }^{32}$ While Deus est is better placed in his episcopal period, the Notus in Iudea Deus may well date to the lectorship. ${ }^{33}$ It is worth noting here that this last treatise deals with the issue of confession in the vernacular, which might be taken as additional material to establish Grosseteste's concerns in this area alongside the composition of the Chateau d'Amour.

\section{Grosseteste and Franciscan Learning}

The nature and impact of Grosseteste's teaching at Greyfriars have been discussed to different purposes and the evidence can be interpreted to differing ends. Michael Robson's recent discussion examines the nature of Grosseteste appointment, his teaching and writing during the period, especially the three sermons to the community, a wider consideration of the theological formation for the brothers, and the continued interest shown to the school by Grosseteste during his episcopal career. Robson notes that 'Grosseteste was the midwife at the birth of the theological tradition in the English province and bequeathed an enduring interest in philosophical, mystical and pastoral texts to the friars. ${ }^{34}$ While it is clear that Grosseteste was influential over the generation of English Franciscans over whom he had charge, the longevity of that influence is more difficult to determine. Cecilia Panti, in her discussion of Grosseteste, Roger Bacon and Thomas Docking, and use and reuse of aspects of Gros-

\footnotetext{
sance Studies 8 (1979), pp. 3-51, repr. in Leonard Boyle, Pastoral Care, Clerical Education, and Canon Law, 1200-1400 (London: Variorum, 1981).

31 Joseph W. Goering and F.A.C. Mantello, 'The Early Penitential Writings of Robert Grosseteste,' Recherches de théologie ancienne et médiévale 54 (1987), pp. 52-111.

32 Goering and Mantello, 'The Meditaciones of Robert Grosseteste,' pp. 118-28; Robert Grosseteste, Templum Dei, c. XXI.3-4, ed. Joseph W. Goering and F.A.C. Mantello (Toronto: Pontifical Institute of Mediaeval Studies, 1984).

33 Siegfried Wenzel, 'Robert Grosseteste's Treatise on Confession, Deus est,' Franciscan Studies 30 (1970), pp. 218-93; Joseph W. Goering and F.A.C. Mantello, 'Notus in Iudea Deus: Robert Grosseteste's Confessional Formula in Lambeth Palace MS 499,' Viator 18 (1987), pp. 253-73.

34 Robson, 'Grosseteste and the Franciscan School,' p. 381. I am much indebted to Robson's discussion of Grosseteste and the Oxford Franciscans; the current discussion approaches similar questions but from different evidential perspectives.
} 
seteste's thought on light rays and the rainbow, points to the rather different and divergent routes taken by the later Franciscan writers. ${ }^{35}$

Part of what will be explored below are treatises known to date from the period of the lectorship, in a manner similar to Robson, but with a different purpose. There is, in Grosseteste's theological works, a frequent use of analogies drawn from his earlier treatises on natural philosophy, a good example being the Hexaemeron. ${ }^{36}$ The 'scientific' works were probably completed by 1229, the theology proper comes perhaps from the mid-1220s, perhaps later, and the Dicta offer a particularly intriguing crossover with the theological. ${ }^{37}$ The interests of Grosseteste's Franciscan students can be brought to the fore in this connection, especially those attributed to Adam of Exeter. In addition, the question of Grosseteste's legacy amongst the Franciscans raises further evidential issues about how that legacy was curated. In the passage from Eccleston quoted above it is Robert Grosseteste 'of sacred memory [a sanctae memoriae]' who is recalled. Eccleston probably compiled his material from the early 1230 s and completed his text by 1258 . Grosseteste was, therefore, by this point deceased, and the early efforts to disseminate records of his sanctity had begun. The later Lanercost Chronicle is equally confident in Grosseteste's holiness, its earlier sections written during the period of the later 13th and early 14 th centuries in which two attempts at canonization were made. Grosseteste's qualities, as holy, learned, and skilled in preaching, as emphasised within the narrative sources are instructive and should be held against the other evidence for his activities at Greyfriars. Association with holiness may have particular rhetorical force.

\section{What did the Brothers Learn?}

As Robson notes the training of friars for pastoral ministry was a central emphasis of Grosseteste's lectorship. How this was done, what curriculum was followed is difficult to state in detail, though important elements can be discerned fairly straightforwardly. There seems to have been an early decision that the Franciscans at Oxford

35 Cecilia Panti, 'The Theological Use of Science at the Oxford Franciscan School: Thomas Docking, Roger Bacon, and Robert Grosseteste's Works,' in The Franciscan Order in the Medieval English Province and Beyond, ed. Michael Robson and Patrick Zutshi (Amsterdam: Amsterdam University Press, 2018), pp. 185-96 at pp. 181-210.

36 Robert Grosseteste, Hexaemeron, ed. Richard C. Dales and Servus Gieben (Oxford: Oxford University Press, 1982). See also Giles E.M. Gasper, 'The Fulfilment of Science: Nature, Creation and Man in the Hexaemeron of Robert Grosseteste,' in Robert Grosseteste and the Pursuit of Religious and Scientific Learning in the Middle Ages, ed. Jack Cunningham and Mark Hocknull, Studies in the History of Philosophy of Mind 18 (Heidelberg: Springer, 2016), pp. 221-42.

37 Joseph W. Goering, 'Robert Grosseteste’s Dicta: The State of the Question,' in Robert Grosseteste and his Intellectual Milieu, ed. John Flood, James R. Ginther, and Joseph W. Goering (Toronto: Pontifical Institute of Mediaeval Studies, 2013), pp. 64-86. 
would not enrol in the Faculty of Arts. ${ }^{38}$ What Grosseteste taught them was probably more theologically orientated, which would fit the suggestions that these years mark his own magistracy in theology but incorporating the liberal arts and natural philosophy as well. It is hard to see why he would not have taught the importance of astronomy, computus, and the notions of heat, motion, light, and body, that his natural philosophical corpus includes. Or, that his commentaries on Posterior Analytics or Physics might not have enjoyed fraternal circulation, as tailored to the aptitude and interests of his students, individually and collectively. That all was bent to a pastoral end, however, is clear from the narrative sources.

Some general statements of the benefits of Grosseteste's teaching are recorded in Thomas of Eccleston's comments on other English Franciscans. Of Peter of Tewkesbury (the Guardian of Greyfriars, London, 1234-36, Custodian of Oxford 1236?-48, Minister of Cologne 1250, and the fifth provincial of England 1254-56x57), Eccleston notes that:

He merited a special love received from the Lord Bishop of Lincoln, from whom he often heard many nuggets of wisdom. For he [Lincoln] said to him [Peter] once that unless the brothers cultivated learning, and studiously devoted to themselves to the divine law, the same thing would certainly happen to us as to other religious who we see walking in the darkness of ignorance, for shame [Isaiah 9:2] $!^{39}$

The emphasis on the importance of learning within the early Oxford Franciscan community is clear, as is the pastoral focus. In this connection Grosseteste's answer to a particular brother on the challenges of preaching are noted in the Lanercost Chronicle:

One time, when a brother asked him whether it was beneficial for the soul to hear foul things abroad in the province to expiate for the souls of others, and defile one's own soul with fetid thoughts as with heaps of dung, he responded with a parable in this way: 'If someone noticed his own kingdom, castle, or court about to be destroyed, having been set on fire, and ordered soldiers and others to act valiantly, and not spare themselves, to extinguish the roused flames, and he also saw some people, leave their work half-burnt, and some people fouled by smoke and soot, he would not on account of this think any less gratefully of them if they had ruined or spoiled the garments they had received from him in order to safeguard his honour. Thus, the Saviour easily restores the beauty of the soul itself, which had been disfigured on account of His honour. ${ }^{40}$

38 Robson, ‘Grosseteste and the Franciscan School,' p. 354.

39 Eccleston, Tractatus De Adventu, Collatio XV, De speciali profectu quorundam fratrum - Concerning a Particular Journey of Certain Brothers, p. 91: 'Ipse speciali dilectione domini Lincolniae ditari meruit, a quo plura secreta sapientiae frequenter audivit. Dixit enim ei aliquando, quod nisi fratres foverent studium et studiose vacarent legi divinae, pro certo similiter contingeret de nobis, sicut de aliis religiosis quos videmus in tenebris ignorantiae, proh dolor! Ambulare.'

40 Lanercost Chronicle, ed. Stevenson, s.a. 1253, pp. 43-44: 'Consulenti se cuidam semel fratri utrumne salubre effet animae in foro provinciae pro aliorum animabus expiandis turpia audire, et conceptionibus fœetidis, quasi quibusdam stercoribus congestis, animam propriam foedare; respondit 
Alongside preaching Grosseteste also addressed the most important emphasis of the Franciscan order, that of poverty. A sermon on Luke 6:20 ('Blessed are the poor for yours is the kingdom of God'), part of the Sermon on the Mount, was delivered to a Friars Chapter in Oxford, between 1229 and $1234 .^{41}$ The sermon, which is also recorded as a treatise Tractatus de scala pauperitatis domini Lyncolniensis (Cambridge, UL MS Ii.I.19, fol. 201a) encapsulates the theological programme outlined above; an exploration of the history of creation, original sin, the restoration of humanity by the Son of God, and the call to conversion. As Michael Robson analyses the sermon, the particular emphasis is on humility: the humility of Incarnation which then forms the pattern for Christian life; humility as an appropriate virtue for the penitent for example in the lives of the saints; the instinct to curb pride; and humble service for example of Paul in serving nascent Christian communities. Grosseteste then moves to pride, which goads people to the accumulation of wealth and falsity, a forerunner in some senses to his annoyance in 1247 at the two English Franciscans who organised the papal tax in that year and adopted too lavish a lifestyle in so doing (at least according to Matthew Paris). The temptations and dangers of wealth are given extra dimension with quotation of Bernard of Clairvaux's Apologia to Abbot William on the architectural excesses of Cluny. ${ }^{42}$ The contemporary context of the building projects at Assisi managed by the sometime Minister General Elias, and the controversy that the grandeur of the construction provoked, should be recalled..$^{43}$ Here, then, Grosseteste brings together his lessons for the Franciscans: poverty does not preclude learning, but learning needs to be focused on its proper object.

\section{The Château d'Amour}

The use of architectural imagery as an explanatory device plays a dominant role in Grosseteste's Anglo-Norman verse-treatise the Château d'amour. An extended treatment of the loss and restoration of creation, the poem incorporates an allegorical de-

parabolice sic, "si quis suum regnum, castrum, vel curiam, abortis incendiis, adverteret destruenda, ac armigeris et aliis juberet fortiter agere, nec sibi parcere ut excitatas flammas extinguerent, videret quoque quosdam de labore semiustos redire, quosdam fumo et fuligine denigratos, non propter hoc minus eos gratos sibi reputaret si indumenta ab eo recepta pro ejus honore salvando corrumperent vel foedarent. Sic Salvator facile animae suum restituit decorem, quae deturpata fuerit propter suum honorem."'

41 Robson, 'Robert Grosseteste's Two Sermons to the Friars Minor,' pp. 110-18; see also Michael Robson, 'Robert Grosseteste and the Greyfriars in the Diocese of Lincoln,' in Robert Grosseteste and the Beginnings of a British Theological Tradition, ed. Maura O'Caroll (Rome: Istituto Storico dei Cappucini, 2003), p. 299 in pp. 289-317; Robson, 'Grosseteste and the Franciscan School,' p. 355. 42 Bernard of Clairvaux, Apologia ad Guillelmum Abbatem, in Sancti Bernardi Opera, vol. 3, Tractatus et opuscula, ed. H. Rochais and J. Leclerq (Rome: Editiones Cistercienses, 1963).

43 Michael Robson, Francis of Assisi (London: Chapman, 1997), pp. 267-68; Anna Welch, Liturgy, Books and Franciscan Identity in Medieval Umbria (Leiden: Brill, 2015), p. 73. 
scription of the Virgin Mary as the castle in which Jesus Christ took refuge. ${ }^{44}$ This comes at about the mid-point of the poem, which begins with a defence of the use of Anglo-Norman: 'So that each in his own language might truly know his God and his redemption, I begin my account in French for those who have no acquaintance with learning or Latin. ${ }^{45}$ A summary of the author's intentions follows: he will speak of the world, why it was made, and given to Adam; of Paradise and heaven, given to him also, then how it was lost, restored, and given back again. ${ }^{46}$ Grosseteste then offers an attenuated account of creation and the fall of humanity in Genesis; he then moves to the story of the four daughters of a powerful king, and his son, by whom the father made all within his realm. The four daughters Mercy, Truth, Justice, and Peace were each given 'a portion of his substance, of his mind, and of his strength. ${ }^{47}$ Arguments amongst the family are used to establish the point the virtue is a unity for God. The poem then moves to the need for Christ to become man, using Anselm of Canterbury's thought on the matter, and the names of Christ as declaimed in Isaiah 9:6: 'Wonderful Counsellor, Mighty God, Everlasting Father, Prince of Peace.' The tour of the castle, with close attention to architectural and military detail, is placed under Wonderful, the evocation of Satan in the wilderness under Counsellor. The poem ends with the last judgment, and finally the entrance of the Prince of Peace. ${ }^{48}$

While older interpretations identify the poem as courtly literature, and date it to the 1250s, the dating of $c .1230$ proposed by the first critical editor seems far more plausible..$^{49}$ Half of the medieval records of the poem give the author's title as Magister, that is 'Master', rather than bishop..$^{50}$ To visit the question of pre-episcopal authorship also begs the question of audience. Mackie, in particular, has advanced the convincing suggestion that the poem was composed for the Franciscans of Oxford. ${ }^{51}$ If this is the case then what is presented is an example of what Grosseteste thought

44 See Abigail Wheatley, The Idea of the Castle in Medieval England (Woodbridge: Boydell and Brewer, 2004).

45 Murray, Le château d'amour de Robert Grosseteste, évêque de Lincoln (Paris: Champion, 1918), p. 89: 'E ke chescun en sun langage / En li conuisse sanz folage, / Son Deu e sa redempcio.' English translation from Evelyn Mackie, 'Robert Grosseteste’s Anglo-Norman Treatise On the Loss and Restoration of Creation, Commonly Known as Le château d'amour: an English Prose Translation,' in Robert Grosseteste and the Beginnings of a British Theological Tradition, ed. Maura O'Carroll, p. 160 in pp. 151-79.

46 Paraphrasing from Mackie, 'Robert Grosseteste’s Anglo-Norman Treatise,' p. 160.

47 Murray, Le château d'amour, p. 95: 'A chescune dona par sei / Sun afferant de sa sustance / De sun sen e de sa puissance.' English translation from Mackie, 'Robert Grosseteste’s Anglo-Norman Treatise.'

48 Mackie, 'Robert Grosseteste’s Anglo-Norman Treatise,' pp. 158-59.

49 Murray, Le château d'amour, p. 64.

50 Mackie, 'Robert Grosseteste’s Anglo-Norman Treatise,' pp. 153-54.

51 Mackie, 'Robert Grosseteste’s Anglo-Norman Treatise,' pp. 154-56. See also her 'Scribal Intervention and the Question of Audience,' in Editing Robert Grosseteste, ed. Evelyn A. Mackie and Joseph Goering (Toronto: Toronto University Press, 2003), pp 61-77. 
appropriate for the communication of essential Christian teachings, both in terms of style and content. The emphasis on the range of analogies and visualization, the focus on an argument of atonement which allows the Devil his rights, go alongside arguments for the necessity of the Incarnation, and the hopefulness for salvation in all of its beauty, reflected by that of the Virgin, order, peace, and joy. Plenty of examples are offered for simple and striking ways to explain the complex arguments discussed. The vernacular offers the suggestion for an intended lay audience, and perhaps a comment on the prior learning and social status of some of the Oxford Franciscans. Although written in the vernacular, the theological frame is that of the Hexameron and De cessatione legalium, as well as Grosseteste's reflections on natural phenomena, or, as might be said, science.

\section{Science and the Dicta}

As noted above, Grosseteste's interests in natural philosophy coincide with the beginning of his lectorship to the Franciscans. It is interesting in this connection to note the place given to the rainbow in the castle section of the Château d'amour. At the centre of the castle, in the middle of the tallest tower, the description reaches its denouement:

Inside this fine and beautiful tower there is an ivory throne which shines more brightly than daylight in midsummer. It is skilfully designed, with seven steps arranged to approach it. Nothing in the world is so beautiful. The rainbow with all its colours extends around it. ${ }^{52}$

Grosseteste's scientific interests provided more than spiritual analogies for the Oxford community. Adam of Exeter, one of the early members, who became close to Grosseteste before leaving on pilgrimage and dying in southern Italy in or around 1232, was the probable author of a text on a treatise On the Ebb and Flow of the Tide, for a long time attributed to Grosseteste. ${ }^{53}$ This makes heavy use in particular

52 Murray, Le château d'amour de Robert Grosseteste, évêque de Lincoln, pp. 106-7: 'En cele bele tur et bone / I ad de ivoire une trone / Ki plus ad en sei blancheur / Ke en mi esté le beau jur. / Par engine est compassez; / Al munter i ad set degrez / Ki par order cochez sunt / Ni a si bele chose el mund / Le arc du ciel entur s'estent / Od la colur k'a li apent.' English translation from Mackie, 'Robert Grosseteste's Anglo-Norman Treatise,' p. 167.

53 Attributions to this text have varied: to Grosseteste in R.C. Dales, 'The Text of Robert Grosseteste's Questio de fluxu et refluxu maris with an English Translation,' Isis 57 (1966), pp. 455-74. Dales changed his mind about the attribution a decade later, preferring Adam Marsh: 'Adam Marsh, Robert Grosseteste, and the Treatise on the Tides,' Speculum 52 (1977), pp. 900-1. Southern preferred an identification with Adam of Exeter, Robert Grosseteste, pp. 122-23, which is followed by Panti, 'Grosseteste and Adam of Exeter's Physics of Light,' pp. 168-73. See also Edgar Laird, 'Robert Grosseteste, Albumasar, and Medieval Tidal Theory,' Isis 81 (1990), pp. 684-94. 
of Abu Ma'shar, although to different conclusions than Grosseteste's own treatment of tides in his On the Nature of Places composed between 1225 and 1229.54

Scientific explanation and analogy abound in another, important set of Grosseteste's writings, the Dicta which have a close relation to his time at Greyfriars. The Dicta consists of 147 pieces, longer and shorter, which may have originated as 'notes for his lectures, disputations, and sermons held in that very building. ${ }^{.55} \mathrm{Al}$ though compiled during his episcopacy they seem to have been written for the most part in a compressed period in the early 1230s. They include commentary on Psalms 1-64, sermons, and other short notes on particular subjects. Dictum 141 provides a good example of the way in which Grosseteste blends his interests to serve an exegetical and moral point:

Humility is the love of persisting in a rank proportionate to one's entire state of being, in the way that arrogance is the love of persisting in a rank higher than appropriate for oneself. This love, moreover, may exist in a human being before they become aware of what is proportionate to themselves according to themselves according to their specific and diverse circumstances. But when the knowledge of ranks proportionate to individual states of being is added to this love, it is as if drawn towards the specific nature of humility.

To make what I am now saying clearer, I will present the following example: the light of the sun is the only light in the sun or in the Ether, having in itself nothing except the nature of light; and as far as its own nature goes, it could exist in this way itself and not be incorporated into these inferior natures. When the sun nevertheless is joined to colour existing in the transparent [thing] through which it passes, for instance the colour of glass, it incorporates itself by necessity in this colour and draws it along with itself, and this colour comes to be in the nature of the light and the light in the nature of the colour, and the colour becomes yellow, or green, or red, in accordance with the colour through which it passes. Nor can this ray not be a coloured ray, even if it is separate from all colour in the Ether or in the sun. ${ }^{56}$

54 Dales, 'The Text of Robert Grosseteste's Questio de fluxu et refluxu maris,' pp. 458-68, English translation at pp. 468-73.

55 Goering, 'Robert Grosseteste's Dicta,' p. 72. Robert Grosseteste, Dicta, transcription of Oxford, Bodleian Library MS Bodley 798 (SC 2656), ed. Joseph W. Goering and Edwin J. Westermann (2003): https://ordered-universe.com/dicta/.

56 Grosseteste, Dictum 141: 'Humilitas est amor persistendi in ordine sibi congruo secundum omnes condiciones suas, sicut superbia est amor persistendi in superiori quam sibi congruit. Iste autem amor potest esse in homine antequam cognoscat que congruant sibi secundum singulas et diversas condiciones. Cum autem huic amori additur cognitio ordinum congruencium condicionum singularum, distrahitur quasi in specialiorem naturam humilitatis. / Ut autem quod nunc dico sit evidencius, pono exemplum tale: Lux solis in sole vel in ethere sola lux est, nichil habens in se nisi naturam lucis, et quantum est de natura sua, talis posset in seipsa existere et numquam incorporari in hiis inferioribus naturis. Cum tamen lux solis adiungitur colori existenti in perspicuo per quod transit, utpote colori vitri, incorporat se necessario illi colori, et trahit secum colorem illum, et fit ille color in natura luminis et lumen in natura coloris, et est radius vel croceus, vel viridis, vel rubeus, secundum quod est color per quem transit. Nec potest illi radius non esse radius coloratus, licet in ethere et in sole sit divisus ab omni colore.' 
The Dictum draws on and moves further than Grosseteste's treatise On Colour, which states that colour is light embodied in something transparent, in this case glass, as well as his enduring interest in light.

Nothing in the collection suggests a peculiarly Franciscan audience, as against a scholastic, and all of the texts are in Latin. Nevertheless, some twenty-seven of the Dicta offer thoughts on the subject of the poor, or more specifically of poverty. ${ }^{57} \mathrm{Dic}$ tum 94 on 'The Opposition of Poverty and Riches' inverts the material understanding of wealth, which is false, and emphasizes Christ as pre-eminently poor. Dictum 143 'That Poverty is Glorious because Similar to the Life of Paradise and Heaven' is one of the shortest:

\begin{abstract}
Since a rich man is said to be one who possesses many things, that poor man is said to be so by virtue of having nothing of his own. According to this understanding of poverty, it appears glorious, because it is similar to the life of paradise and the life of heaven. For in the happiness of paradise, before the fall of humanity, nothing was owned personally. Similarly, in the country of heaven there will be no possessions, but all things in common for all; so, the reward of the kingdom of heaven is properly promised to poverty. ${ }^{58}$
\end{abstract}

Natural phenomena, biblical exegesis, preaching, and practical Christianity characterize the Dicta and make them, alongside their general scholastic valance, a potentially intriguing insight into Franciscan learning under Grosseteste.

\title{
Library and Legacy
}

It is, unfortunately, difficult to know the extent of the library resources open to the friars at Oxford; the library suffered badly at the dissolution, and no catalogue survives. That said, and as Kathryn Humphreys has demonstrated, some of the library can be reconstructed from comments by medieval readers, which occasionally include mention of pressmarks. As she states, 'This is mainly due to the presence of books and working notes inherited from Robert Grosseteste. 59 How far any of these mentions can be taken to refer to the early years of the house is moot, but the references include the commentary on the Physics, according to notes made by William of Alnwick and a glossed version of Abu Ma'shar by Grosseteste, which is

57 Grosseteste, Dicta 2, 11, 13, 23, 30, 35, 36-37, 46, 50, 52, 57, 61, 72, 84, 90, 91, 100, 102-3, 108, 116, 137, 140, 147.

58 Grosseteste, Dictum 143: 'Cum Dives dicatur qui multa possidet propria, ille merito pauper dicetur qui nichil habet proprium. Secundum hanc itaque racionem paupertatis apparet paupertas gloriosa, quia vite paradisi et vite celesti similima. In felicitate namque paradisi, ante hominis lapsum, nichil fuit proprium. Similiter in celesti patria nulla erunt propria, sed omnibus omnia communia, unde bene promittitur paupertati premium regni celorum.'

59 The Friars' Libraries, ed. K.W. Humphreys (The British Library in association with The British Academy, 1990), F9 Oxford Franciscans, p. 224 in pp. 224-29. 
indicated from John Lathbury, from the mid-14th century, in a treatise On Lamentations: 'Hic notandum quod in libro Lincolniensis Oxonie scribitur sic in glosa etc. ${ }^{60}$ An interesting note which may relate to the Dicta is found in Corpus Christi College, Oxford, MS 251, f. 83v: 'The square of a circle: Let there be a semicircle around the straight line $\mathrm{AB}$... to which is subtended a squared side. I found this demonstration in Oxford in a certain note [cedula for schedula] of the Lord of Lincoln.'61

This is in addition to the Hexaemeron, copies of which at Greyfriars are referenced by both Thomas Netter and Thomas Gascoigne. The former records a marginal note to the effect that:

Hence, also in a certain book from the study of the Great Lincolnite, which I saw amongst the Franciscans of Oxford, [which] had a note in the margin in the hand of the Great Lincolnite: 'Note that accidents can be divided from the subject, for instance light from heat,' with a long treatise ending with the words 'stellam signatam [a specific star]. ${ }^{62}$

A number of letters, several sermons on luxury and education, the commentary on Psalms 1-100 and commentary on Paul, complete the references to the Greyfriars collection. On the evidence of the catalogues and bibliographical indicators the Oxford community preserved more of Grosseteste than other Franciscan houses; this is hardly surprising in view of the donation of his books to the library, facilitated by Adam Marsh as noted by Nicholas Trevet. ${ }^{63}$

\section{Pastoral Lessons to the Franciscans}

English Franciscan historiography leaves no doubt as to the high esteem in which the order held Grosseteste from the mid-13th century onwards, honored in particular for his teaching and learning. Within the tradition too comes an occasional glimpse of a more personal side to his interactions with the community, as opposed to individuals like Adam Marsh, or Adam of Exeter, with whom he corresponded. The Lanercost Chronicle offers one such vignette, in a record of a strange episode, involving a dying novice.

This man [Grosseteste] was the first to direct the studies of the Franciscan scholars at Oxford, as a result of which he was also raised to direct the studies at the place. At this time it happened

60 Friars' Libraries, p. 225.

61 Friars' Libraries, p. 224: 'Quadratura circuli. Esto circa lineam rectam AB semicirculus (...) cui subtenditur latus quadrata. Hanc demonstracionem inueni Oxon' in quadam cedula domini Lincol'.' 62 Friars' Libraries, p. 225: 'Unde et in libro quodam de studio magni Lincolniensis, quem vidi inter Minores Oxoniarum, habebat notatum in margine de manu magni Lincolniensis "Nota quod diuidi possunt accidentia a subiecto, ut lux a calore, cum longo tractu et in fine eius stellam signatam.", 63 Trevet, Annales, ed. Hog, p. 243: '(...) ob cuius affectionem libros suos omnes conventui fratrum Minorum Oxoniae in testament legavit.' 
that, among the brothers, a certain young novice was taken ill, to the point when it seemed that his end approached. After the indulgence of his soul had been sought for him in haste, according to custom, he said, as if saying farewell, to all the brothers standing around him that 'you holy and honourable men, I give thanks to God and to you for my conversion, and moreover to you in particular for the teaching, example, and fellowship that you have offered to me for the last twelve weeks. You will have known that I see the path to my salvation, and on account of the limited period I spent with you, I am numbered among the twelve holy apostles.'

Having said these words he turned inwards and was silent for a long time. The simple brothers were marvelling and exulting and awaiting the outcome. He who was about to depart, was shaken by the suffering of death, and shouted with a loud voice, 'Lord', he said, 'do you truly punish, do you truly strike? I should say you strike in order to spare and punish in order not to punish!' The brothers ran to him, and thinking he had lost his mind, they took some things from him, and stuffed other things in his ears; and in this way the innocent soul departed to the life that was not denied him. The brothers went to see Robert, he being their teacher, and explained what had happened. They implored him to say what he thought.

He said, 'I consider you to have acted rashly, for he [the dead novice] was reading from the book of life, and you would have learned, had he continued, many secret things of God. ${ }^{.64}$

This passage offers an image of Grosseteste at Oxford preserved, presumably, amongst the community, retold to the friar responsible for the chronicle. It is an image of authority, correction, and parental reproval, framed in the hope of salvation and the virtues of the brotherhood, however much they may have misjudged the situation. Grosseteste's task was to prepare the friars for their life of ministry, and, as far as the evidence shows, he did so successfully, bringing together all facets of his learning and experience: of scientific inquiry, theology, and pastoral care. His formation of the community at Oxford, and his influence on the first generations of Franciscan scholars both here, and, by wider networks at Paris, from Adam Marsh to Alexander of Hales, should not be underestimated, and is perhaps worth more em-

64 Lanercost Chronicle, ed. Stevenson, s.a. 1235, p. 45: 'Vir iste primus cathedram scholarum fratrum Minorum rexit Oxoniae, unde et assumptus fuit ad cathedram praelatiae. Quo tempore contigit inter fratres, ut quidem novicius, aetate juvenis, infirmitate superveniente, tandem ad exitum videretur properare, properatis sibi secundum morem animae stipendiis, circumstantibus omnibus fratribus, quasi valefacturus ait, "viri sancti et honesti, Deo gratias ago et vobis de conversione mea, insuper vobis specialiter de doctrina, exemplo et confortio mihi iam per duodecim hebdomodas praestitis; viam noveritis salutis meae conspicio, et pro modico quod vobiscum confeci spatio, connumeratus sum in sanctorum apostolorum duodenario." His dictis introrsus rediens diu filuit, fratribusque simplicibus mirantibus et exultantibus, et rei eventum expectantibus, is qui profecturus erat, cum passione lethali vexaretur, voce alta clamavit, "Domine," inquit, "nunquid punis, nunquid percutis? immo percutis ut parcas, punis ut non punias!” Accurrentes fratres, et eum alienatum putantes, surripuerunt ei talia, et alia auribus eius inculcaverunt; et sic innocens anima ad vitam quae non veteratur abcessit. Adeuntes fratres Robertum, utpote paedagogum, exponunt quid evenerit; supplicant ut dicat quid senserit. "Ego," inquit, "reputo vos temerarie egisse, quoniam ille legebat in libro vitae, et vos docuisset, si continuasset, multa Dei secreta.”" 
phasis in the general accounts of the order. ${ }^{65}$ While he held reservations about the sustainability of a total reliance on mendicancy, seeing the productive practices of the Beguines as worthy of the highest praise, his advocacy of the Franciscans within universities anticipated many of the arguments put against them, and the Dominicans, in the 1250 s. ${ }^{66}$ What Grosseteste offered above all was a framework whereby the community could hold in creative tension the life of poverty and the life of learning.

65 See Giles E.M. Gasper, 'Creation, Light, and Redemption: Hexaemeral Thinking, Robert Grosseteste, and the Summa Halensis,' in The Summa Halensis: Sources and Context, ed. Lydia Schumacher (Berlin: De Gruyter, 2020), pp. 295-316.

66 Eccleston, Tractatus De Adventu, pp. 98-99. 
